\title{
Verschuivend paradigma in corporate governance bij vijandige overnames
}

\author{
Reflecties van rechters, bestuurders en commissarissen, een lid \\ van de Monitoring Commissie en een institutionele belegger \\ tegen de achtergrond van ontwikkelingen op de kapitaalmarkt \\ en in de jurisprudentie
}

\author{
J. Nijland, T.L.M. Verdoes, M.P. Lycklama à Nijeholt \& N.T. Pham
}

\section{$1 \quad$ Inleiding}

In geval van een vijandige overname neemt het risico van kortetermijndenken toe en kan het duurzaam creëren van waarde onder druk komen te staan. Partijen moeten - vaak in een hectische fase, waarin onherroepelijke besluiten kunnen worden genomen en risico's worden gelopen - laveren tussen uiteenlopende belangen. Een methode om 'meer duurzame vijandige overnamebesluiten' te bewerkstelligen, is het integreren van langetermijnwaardecreatie als een rechtsnorm in het corporate-governancesysteem. Langetermijnwaardecreatie als norm zou een vijandige overname, die de langetermijnwaardecreatie van de betrokken vennootschap kan schaden, kunnen verhinderen. De recente ontwikkelingen in de Nederlandse jurisprudentie en de herziening van de Corporate Governance Code zouden kunnen dienen als een belangrijke katalysator voor meer 'duurzame' overnamebesluiten door het benadrukken van het belang van langetermijnwaardecreatie. Wij interviewden acht rechters, een lid van de Monitoring Commissie, CEO's, commissarissen en een institutionele belegger over de rol van deze norm tegen de achtergrond van ontwikkelingen in de kapitaalmarkten en de wet- en regelgeving (corporate governance en jurisprudentieonderzoek). Daaruit blijkt een brede consensus voor langetermijnwaardecreatie als richtsnoer voor het beoordelen van vijandige overnames onder rechters, de Monitoring Commissie en bestuurders en commissarissen. Institutionele beleggers blijken nog moeite te hebben met langetermijnwaardecreatie als richtsnoer bij een vijandige overname.

In dit artikel wordt bezien of langetermijnwaardecreatie als norm zou kunnen gelden voor het handelen van de bestuurders en commissarissen van een doelvennootschap in geval van een vijandige overname. In paragraaf 2 worden enkele beschouwingen over de ontwikkelingen van de kapitaalmarkten gegeven. In paragraaf 3 worden kort twee essentiële structurerende elementen van de corporate-

* De auteurs danken Leander van den Hof, onderzoeksassistent aan de Universiteit Leiden, voor zijn bijdrage aan dit artikel. 
governancediscussie behandeld: de vennootschapsdoelstelling en het zelfstandige vennootschapsbelang. Vervolgens wordt in paragraaf 4 aan de hand van jurisprudentie beknopt de ontwikkeling geschetst van deze structurerende elementen. Dit wordt gevolgd door de resultaten van de diepte-interviews met belangrijke actoren in overnameconflicten (par. 5). We sluiten af met een conclusie (par. 6), waarin de implicaties van de onderzoeksresultaten voor de theoretische discussie worden aangegeven.

\section{Ontwikkelingen in de kapitaalmarkt}

Er bestaat een sterke overtuiging dat kapitaalmarkten kunnen bijdragen aan de langetermijnwaardecreatie van ondernemingen en daarmee samenhangend de economische groei en welvaart. ${ }^{1}$ Deze overtuiging is mede gebaseerd op een ideale eigenschap die aan kapitaalmarkten wordt toegedicht: de efficiëntie. In een efficiënte kapitaalmarkt zijn prijzen een weerspiegeling van alle relevante informatie en zijn beurskoersen de best beschikbare inschatting van de fundamentele waarde van de onderneming. ${ }^{2}$ Vanaf de jaren negentig lag de focus van beleidsmakers op het bestrijden van misbruik, het rapporteren van misleidende informatie, fraude, belangenverstrengeling en voorkennis: het verminderen van de informatieasymmetrie. ${ }^{3}$ De efficiënte markthypothese werd het ideologische fundament om deze 'market failures' te elimineren, bijvoorbeeld door meer frequente verslaggeving, zoals kwartaalrapportages.

Een daaraan gerelateerde overtuiging is dat de vennootschap als een verlengstuk van haar aandeelhouders wordt beschouwd. ${ }^{4}$ Anonieme aandeelhouders worden gezien als perfecte en efficiënte monitors van bestuurders. Indien de vennootschap afstapt van maximalisatie van aandeelhouderswaarde, zal zij door de markt worden gedisciplineerd, aangezien aandeelhouders de aandelen van de vennootschap zullen verkopen ('stemmen met de voeten'). Dit zal de waarde van de aandelen verlagen, wat de vennootschap vatbaarder maakt voor een (vijandige) overname. $^{5}$

De vennootschap wordt zodoende op voorhand gedisciplineerd. Het concept van aandeelhouderswaarde biedt dus door de indirecte monitoring door de kapitaal-

1 R. Levine, Financial development and economic growth. Views and agenda, Journal of Economic Literature (XXXV) 1997, p. 688-726.

2 E.F. Fama, Efficient capital markets. A review of theory and empirical work, The Journal of Finance (25) 1970, afl. 2, p. 383-417.

3 J. Kay, The Kay review of UK equity markets and long-term decision making, 2012. De opleving van de 'aandeelhouderswaarde'-beweging wordt meestal toegeschreven aan M.C. Jensen \& W. Meckling, Theory of the firm. Managerial behaviour, agency costs, and capital structure, Journal of Financial Economics (3) 1976, afl. 4, p. 305-360, zie J. Fox \& J.W. Lorsch, What good are shareholders?, Harvard Business Review (90) 2012, afl.7, p. 49-57.

$4 \quad$ Fox \& Lorsch 2012.

5 De overnamemarkt ('market for corporate control') heeft een disciplinerende functie: M.C. Jensen \& R.S. Ruback, The market for corporate control, Journal of Financial Economics (11) 1983, p. $5-50$. 
markt een efficiënt mechanisme om het gedrag van managers te sturen. Aandeelhouderswaarde is hiervoor een geschikte maatstaf, immers: '[P] urposeful behavior requires a single valued objective function. ${ }^{6}$

De scheiding tussen leiding en eigendom ('separation of ownership and control') staat aan de basis van het klassieke conflict tussen bestuurder en aandeelhouders. ${ }^{7}$ De bestuurder (agent) heeft een informatievoorsprong op de aandeelhouders (principalen). De efficiëntie kan worden bevorderd door de kapitaalmarkten te voorzien van tijdige, relevante en betrouwbare financiële informatie. De nadruk in de corporate governance komt zodoende meer te liggen op de aandeelhouderswaarde ${ }^{8}$ als de verbindende schakel tussen de vennootschap en de aandeelhouders. De kapitaalmarkt is het mechanisme om die waarde zichtbaar te maken - indien deze markten efficiënt zijn, is de beurskoers de perfecte maatstaf om de prestaties van bestuurders te beoordelen.

Marktefficiëntie impliceert namelijk dat het conflict tussen korte en lange termijn, tussen aandeelhouderswaarde ${ }^{9}$ en stakeholderswaarde, niet aan de orde is. Een efficiënte markt houdt namelijk rekening met toekomstige gevolgen en reacties van alle stakeholders. Recente ontwikkelingen op de kapitaalmarkt lijken de efficiënte-markthypothese echter te ondermijnen. ${ }^{10}$ Kapitaalmarkten zijn internationaler, anoniemer en diffuser geworden. Dankzij de toegenomen specialisatie binnen de 'beleggingsketen' ('equity investment chain') is het aantal intermediairs sterk toegenomen. Binnen die keten worden actoren veelvuldig gemonitord met behulp van benchmarks. Het oorspronkelijke model, gebaseerd op governance van relaties, is daardoor geëvolueerd in een model gebaseerd op transacties. Bovendien blijkt de financieringsfunctie van kapitaalmarkten beperkt; hun hoofdfunctie is meer gericht op het bieden van liquiditeit van de aandelen van grote multinationals. ${ }^{11}$ De rol van de kapitaalmarkten in het kader van vijandige overnames, evenals het onderliggende corporate-governancesys-

6 M.C. Jensen, Value maximization, stakeholder theory, and the corporate objective function, Journal of Applied Corporate Finance (14) 2001, afl. 3, p. 8-21.

7 Jensen \& Meckling 1976.

8 Kay 2012. G.T.M.J. Raaijmakers, De financiële markt en het ondernemingsrecht, Ondernemingsrecht 2009/104, p. 430-442, constateert ten aanzien van de Nederlandse corporate governance '(...) de toegenomen invloed van de financiële markt op de corporate governance van Nederlandse beursondernemingen. Door al deze ontwikkelingen is ons stakeholdersmodel onder druk komen te staan en zijn wij opgeschoven naar een meer aandeelhoudersgericht systeem.' Deze ontwikkeling stelt hij ter discussie door het onderkennen van zeven beperkingen van de financiële markt.

9 R.A. Brealey, S.C. Myers \& A.J. Marcus, Fundamentals of corporate finance, McGraw-Hill, New York, 2018, p. 13 geven aan dat winstmaximalisatie geen goed gedefinieerd doel van de vennootschap kan zijn vanwege het feit dat de langetermijneffecten daarin niet goed tot uitdrukking komen. Een vennootschap zou de winst kunnen laten stijgen door op research en development te bezuinigen. De ironie is dat door de druk van de kapitaalmarkten het streven naar aandeelhouderswaarde vennootschappen juist aanzet tot kortetermijngedrag.

10 A. Haldane, Patience and finance. Speech tijdens het Oxford China Business Forum, Beijing, 9 september 2010.

11 Eumedion, Position paper. The future of the public equity market from the perspective of Dutch institutional investors, Corporate Governance Forum 2014. 
teem, zou wellicht kritisch moeten worden heroverwogen. Bij een dergelijke benadering van de corporate governance biedt het Nederlandse voorbeeld een veelbelovend perspectief door zijn gerichtheid op het belang van de vennootschap en de daaraan verbonden onderneming als een gescheiden belang in combinatie met het doel van langetermijnwaardecreatie; deze benadering overstijgt de klassieke tweedeling van stakeholders- en stakeholdersbelang. ${ }^{12}$ Dit beeld rijst op bij de chronologische analyse van de rechtspraak (zie par. 4).

\section{Langetermijnwaardecreatie in de corporate governance van de vennootschap: twee structurerende elementen van de (beursgenoteerde) vennootschap}

In corporate governance dienen het vennootschapsdoel ${ }^{13}$ en het vennootschapsbelang ${ }^{14}$ als baken voor het handelen van bestuurders. Als zodanig zijn deze begrippen volgens ons structurerend in de corporate governance van de vennootschap. Langetermijnwaardecreatie krijgt in de regelgeving, de jurisprudentie en de bestuurskamers een steeds prominentere rol bij het bepalen van het vennootschapsbelang. Dit blijkt ook uit de interviews. In deze paragraaf wordt besproken dat de twee structurerende elementen ruimte bieden voor het individualiseren van de langetermijnwaardecreatie als identificeerbare norm: het concretiseren ervan in een specifieke context. Een onderneming is een georganiseerde economische activiteit. (Grote) ondernemingen zijn normaliter georganiseerd in vennootschappen, waardoor zij kunnen deelnemen aan het economisch verkeer - ondernemingsrecht faciliteert 'het ondernemen'. ${ }^{15}$ Een vennootschap en de daaraan verbonden onderneming kunnen deelnemen aan het economisch verkeer als ware de vennootschap een natuurlijk persoon. ${ }^{16}$ Vennootschappen beschermen de investeringen in de onderneming om de door de onderneming

12 In deze inleiding is vooral de shareholderbenadering besproken omdat corporate governance in de jaren negentig en het begin van deze eeuw naar aandeelhouderswaarde toe is geëvolueerd, zie Raaijmakers 2009. Bovendien is de 'most serious omission of stakeholder theory that it underemphasizes firms' role in creating values', J. Kraaijenbrink, A value-oriented view of strategy (working paper), University of Twente, 2010.

13 Art. 2:7 BW

14 Art. 2:129 lid 5 BW.

15 Daarnaast heeft ondernemingsrecht een regulerende functie: B.F. Assink, De Januskop van het ondernemingsrecht - over faciliëring en regulering van ondernemerschap, Ondernemingsrecht 2010, p. 248-259.

16 Art. 2:5 BW. 
gecreëerde waarde te 'oogsten' ('value creation' en 'value capturing'). ${ }^{17}$ Door het bestaan van liquide kapitaalmarkten kunnen individuele aandeelhouders dagelijks uitstappen en kan de vennootschap de tijdshorizon van de individuele aandeelhouders overstijgen. Sterker, de vennootschap kan de tijdshorizon van elke (andere) stakeholder die een bijdrage levert aan de onderneming overstijgen. Vennootschappen dienen dus als een vehikel om de op de lange termijn gerichte investeringen van ondernemingen te structureren. Bij de inrichting van de governance van de vennootschappen is het van groot belang dat de onbeperkte tijdshorizon in acht wordt genomen. Hierbij spelen twee structurerende elementen een rol: de doelstelling en het zelfstandige belang van de vennootschap.

\subsection{Eerste structurerend element: vennootschapsdoelstelling}

Het eerste essentiële structurerende element is dat de vennootschap wettelijk gezien een (in de statuten) gespecificeerd doel heeft. De akte van oprichting dient de statuten van de vennootschap te bevatten en deze statuten moeten het doel van de vennootschap vermelden. ${ }^{18}$ In beginsel is het doel van de vennootschap het ontwikkelen van activiteiten met een bepaald resultaat. ${ }^{19}$ Veel rechtsstelsels hanteren een open en neutrale benadering bij het vaststellen van het doel van de vennootschap. Met andere woorden: er is geen ondernemingsrechtelijke regel die vereist dat het doel van de vennootschap bepaalt dat de onderneming zich moet richten op de maximalisatie van aandeelhouderswaarde voor de korte of lange termijn. ${ }^{20}$ Een nadruk op langetermijnwaardecreatie is dus niet uitgesloten.

\subsection{Tweede structurerend element: het zelfstandige vennootschapsbelang}

Het inzicht dat een vennootschap een rechtspersoon is met een definieerbaar doel, gaat gepaard met de erkenning dat de vennootschap kan worden beschouwd als een entiteit met een eigen belang, die kan worden onderscheiden van het belang van betrokkenen bij of belanghebbenden van de vennootschap en haar activiteiten. ${ }^{21}$ In een serie uitspraken in het kader van overnames heeft de Hoge Raad het onderscheid tussen het belang van de vennootschap en het belang van

17 De essentie van het ondernemingsrecht is gelegen in de affirmative asset partitioning - bescherming van de vennootschap tegen de schuldeisers van de aandeelhouders - en niet de defensive asset partitioning - bescherming van de aandeelhouders tegen de schuldeisers van de vennootschap, zie H. Hansmann \& R. Kraakman, The essential role of organizational law, Yale Law Journal (110) 2000, afl. 387, p. 390-440: 'At its essential core, organizational law is property law, not contract law. In particular, organizational law permits the formation of a floating lien on the pool of assets associated with a firm, and permits as well the assignment of that lien to the constantly changing group of creditors who transact with the firm, while shielding those assets from creditors of the firm's managers and owners.'

18 Vgl. art. 2:66/177 BW en section 31 UK Companies Act, 2006.

19 B.F. Assink, Belang van de vennootschap, overname en algemeen belang, WPNR 2015/7048, p. 103.

20 Bijv. art. 2:66 lid 1 BW.

21 J.M.M. Maeijer, Het belangenconflict in de naamloze vennootschap (oratie Nijmegen), Deventer: Kluwer 1964; Assink 2015, p. 105; B. Kemp, Aandeelhoudersverantwoordelijkheid: de positie en rol van de aandeelhouder en aandeelhoudersvergadering (diss. Maastricht; Serie vanwege het Van der Heijden Instituut, deel 129), Deventer: Wolters Kluwer 2015, par. 3.13.6. 
andere betrokkenen bij de vennootschap uitdrukkelijk erkend. Uitgaande van een solvente en op continuïteit gerichte vennootschap als normaaltype, geeft de jurisprudentie kortweg aan dat het doel van de vennootschap is om het belang van de onderneming te bevorderen. $\mathrm{Na}$ Cancun, ${ }^{22}$ waarin de Hoge Raad expliciet het zelfstandige belang van ondernemende vennootschappen onderscheidt van de belangen van stakeholders van de vennootschap, schrijft de herziene Nederlandse Corporate Governance Code 2016 voor, dat het doel van de vennootschap gericht is op 'langetermijnwaardecreatie', 23 terwijl het standpunt van de Monitoring Commissie Corporate Governance Code vóór de herziening van de Code is, dat de vennootschap streeft naar 'het creëren van aandeelhouderswaarde op de lange termijn' (cursivering toegevoegd). ${ }^{24}$ Nederland staat in deze ontwikkeling niet alleen. In Europa hebben Duitsland, Zweden, Noorwegen, Denemarken, Oostenrijk en België het belang van duurzame waardecreatie reeds benadrukt. ${ }^{25}$

Paragraaf 4 schetst de ontwikkeling in de jurisprudentie van 1971 tot 2018 in vijandige overnames over het doel en de identiteit van de vennootschap. In interviews hebben wij belangrijke actoren in het krachtenveld van vijandige overnames laten reflecteren op deze ontwikkelingen. De resultaten hiervan worden weergegeven in paragraaf 5 .

\section{Vijandige overnames in jurisprudentie}

De jurisprudentie wordt hierna chronologisch weergegeven, waarbij volgens ons belangrijke kantelpunten en tijdvlakken voor het denken over langetermijnwaardecreatie als norm worden aangegeven.

In de vroegere zaken beoordelen rechters beschermingsmaatregelen in overnamesituaties op basis van de redelijkheid en billijkheid. ${ }^{26}$ Het uitgangspunt in deze eerste uitspraken is dat een beschermingsmaatregel gerechtvaardigd is, indien er 'een (...) bedreiging' is 'voor de continuïteit en eigen identiteit' van de vennootschap. ${ }^{27}$ Deze redenering wordt bevestigd in latere uitspraken. ${ }^{28}$ Langetermijnwaardecreatie wordt niet expliciet genoemd, maar in Immofarm worden in 1971 wel 'de continuïteit van de onderneming', 'haar zelfstandig voortbestaan' en 'het behoud van haar eigen (Nederlands) karakter en van het personeel' genoemd als de verplichtingen van het bestuur en de raad van commissarissen

22 HR 4 april 2014, ECLI:NL:HR:2014:797, r.o. 4.2.1, NJ 2014/286 (Cancun).

23 Zie de preambule van de Nederlandse Corporate Governance Code 2016 en art. 1.1.1 van de Code.

24 Zie de preambule van de Nederlandse Corporate Governance Code 2003, onder par. 3.

25 Zie de Corporate Governance Codes van deze landen, art. 4.1.1 (CGC 2017 Duitsland), art. 3.1 (CGC 2016 Zweden), p. 32 en 48 (CGC 2014 Noorwegen), art. 4 (CGC Denemarken 2017), preambule, art. 26a (CGC Oostenrijk 2018), preambule onder par. 2, en art. 1.1 (CGC België 2009).

26 Hof Amsterdam (OK) 1 april 1971, ECLI:NL:GHAMS:1971:AB6704 (Immofarm AG/NV Handelsvereeniging v/h Reiss en Co e.a.); Rb. Haarlem 12 juni 1990, ECLI:NL:RBHAA:1990:AC2566 (Asko/Ahold).

27 Rb. Haarlem 12 juni 1990, ECLI:NL:RBHAA:1990:AC2566 (Asko/Ahold), zie r.o. 6.6.

28 Hof Amsterdam (OK) 23 januari 2009, JOR 2009/69 (Beheermaatschappij Trial). 
jegens de vennootschap bij het behartigen van het vennootschappelijk belang. ${ }^{29}$ De redelijkheid en billijkheid bakent de verplichting van het bestuur af om beschermingsmaatregelen te nemen in het vennootschapsbelang, mits de beschermingsmaatregel andere belangen niet onevenredig schaadt. ${ }^{30}$

In GTI Holding formuleert Rechtbank Utrecht twee objectieve criteria om te spreken van een bedreiging van de onafhankelijkheid en zelfstandigheid van de vennootschap waartegen het bestuur maatregelen mag nemen: 'De bieder moet blijk hebben gegeven van vijandige intenties, en de acties van de partij met de vijandige bedoelingen moeten een bedreiging kunnen vormen voor de zelfstandigheid en onafhankelijkheid van die vennootschap.'31

Een bedreiging voor het belang van de vennootschap fungeert dus als een veilige haven voor besturen van doelvennootschappen om beschermingsmaatregelen te nemen, mits zij binnen de grenzen van de redelijkheid en billijkheid blijven, dat wil zeggen geen onevenredig nadeel toebrengen aan andere belanghebbenden. ${ }^{32}$ Het argument van de veilige haven kan tevens worden afgeleid uit de Heineken Holding NV-uitspraak, ${ }^{33}$ die acht jaar na GTI Holding wordt gewezen. ${ }^{34}$

In de RNA-beschikking formuleerde de Hoge Raad voorwaarden voor rechtmatige bescherming van het vennootschapsbelang. ${ }^{35}$ De open structuur van RNA (RNA kende geen statutaire beschermingsconstructie) kan redelijke verwachtingen opwekken. Desondanks kan, aldus de Hoge Raad in RNA, het hebben van een open structuur het nemen van een beschermingsmaatregel door het bestuur van de doelvennootschap naar de eisen van redelijkheid en billijkheid toch gerechtvaardigd worden indien deelbelangen niet onevenredig of onnodig worden geschaad (adequate en proportionele reactie). ${ }^{36}$

29 Dit valt onder de taak van het bestuur en wordt erkend als een rechtmatig belang voor het nemen van een beschermingsmaatregel. Hof Amsterdam (OK) 1 april 1971, ECLI:NL:GHAMS: 1971:AB6704 (Immofarm AG/NV Handelsvereeniging v/h Reiss en Co e.a.), r.o. 6.8. Aangezien de legitimiteit van een beschermingsmaatregel kan afhangen van de vraag of de continuiteit of identiteit van de vennootschap in gevaar is, wordt het besluit van het bestuur van een doelvennootschap om een beschermingsmaatregel te nemen niet gezien als strijdig met de maatstaven van redelijkheid en billijkheid en dientengevolge niet onrechtmatig. Rb. Haarlem 12 juni 1990, ECLI:NL:RBHAA:1990:AC2566 (Asko/Ahold), r.o. 6.6-6.8.

30 Boven op dit Immofarm-criterium, verlangde Rechtbank Haarlem in Asko/Ahold, dat het nemen van een beschermingsmaatregel niet alleen in het vennootschapsbelang diende te zijn, maar ook dat de beschermingsmaatregel niet het belang van de 'overvaller' onevenredig nadeel toebrengt. Rb. Haarlem 12 juni 1990, ECLI:NL:RBHAA:1990:AC2566 (Asko/Ahold), r.o. 6.6.

31 Rb. Utrecht 15 september 1993, ECLI:NL:RBUTR:1993:AC4321 (GTI Holding), zie r.o. 5.6-5.7.

32 Rb. Utrecht 15 september 1993, ECLI:NL:RBUTR:1993:AC4321 (GTI Holding), zie r.o. 5.9.

33 Hof Amsterdam (OK) 18 oktober 2001, ECLI:NL:GHAMS:2001:AD4646, NJ 2001/641 (Heineken Holding NV).

34 Hof Amsterdam (OK) 18 oktober 2001, ECLI:NL:GHAMS:2001:AD4646, NJ 2001/641 (Heineken Holding NV), zie r.o. 3.8.

35 HR 18 april 2003, ECLI:NL:HR:2003:AF2161 (RNA/Westfield), r.o. 3.7.

36 HR 18 april 2003, ECLI:NL:HR:2003:AF2161 (RNA/Westfield). 
In de Stork-uitspraak uit 2007 wordt voor het eerst beslist dat het bestuur van de vennootschap verplicht is om rekening te houden met de belangen van alle stakeholders. ${ }^{37}$ In ASMI (2010) nam de Hoge Raad expliciet afstand van de internationale corporate-governancetrend die gericht was op langetermijnaandeelhouderswaarde en als zodanig ook is verwoord in de preambule van de Code Tabaksblat van 2008 en 2003. Sterker, de Hoge Raad corrigeerde de normstelling in de Code Tabaksblat, door voor te schrijven dat het bestuur het belang van alle betrokkenen bij de vennootschap op lange termijn in aanmerking dient te nemen, wat 'in overeenstemming is met' de Code Tabaksblat 2008 en 2003, die 'een uiting vormt van de in Nederland heersende algemene rechtsovertuiging welke mede inhoud geeft aan i) de eisen van redelijkheid en billijkheid, en ii) de eisen die voortvloeien uit een behoorlijke taakvervulling. ${ }^{38}$

Waar in Stork, ABN AMRO en ASMI van bestuurders een bredere stakeholderoriëntatie wordt gevergd en de Hoge Raad in ABN AMRO bestuurders uitdrukkelijk voorschrijft het belang van de vennootschap voorop te stellen, is de primaire taakgerichtheid van het bestuur op het vennootschappelijk belang pas in 2013 ingetreden ex art. 2:129/239 lid 5 van het Burgerlijk Wetboek (BW).

De codificatie van art. 2:129/239 lid 5 BW heeft eraan bijgedragen dat in 2014 de Hoge Raad in Cancun zijn progressieve, rechtsvormende uitspraak doet. ${ }^{39}$ De Cancun-beschikking kent een tweeledige normstelling: gericht tot de vennootschap en gericht tot de bestuurder. Als eerste kent de Hoge Raad ondernemende vennootschappen een bijzondere positie toe door van deze vennootschappen te verlangen dat zij het bestendige succes van de onderliggende ondernemingen bevorderen.

De tweede normstelling is gericht aan het bestuur, waarbij de Hoge Raad voorschrijft dat het bestuur zich in de eerste plaats moet richten naar het belang van de vennootschap en de met haar verbonden onderneming (art. 2:129/239 lid 5 BW). In de tweede plaats dient het bestuur bij het uitvoeren van die wettelijke taak, op grond van de maatstaven van redelijkheid en billijkheid, zorgvuldigheid te betrachten met betrekking tot de belangen van alle stakeholders van de vennootschap.

Drie jaar later wordt Cancun op de proef gesteld. In de Akzo Nobel-beschikking herhaalt de Ondernemingskamer de normen van Cancun en geeft daarnaast rechtsgevolg aan de herziene Corporate Governance Code 2016:

37 Aangezien het bestuur van Stork primair verantwoordelijk is voor het bepalen van de strategie van de vennootschap en brede steun geniet van belangrijke stakeholders voor de gekozen (succesvolle) strategie, merkt de Ondernemingskamer de strategie aan als gezond. Dit heeft tot gevolg dat Stork niet gehouden is om haar stand-alone strategie op te geven en te kiezen voor de plannen van de activistische aandeelhouders, die zouden leiden tot zeer hoge risico's voor alle stakeholders. Hof Amsterdam (OK) 17 januari 2007, ECLI:NL:GHAMS:2007:AZ6440 (Stork), zie r.o. 3.16-3.17 en HR 13 juli 2007, ECLI:NL:HR:2007:BA7972, NJ 2007/434 (ABN AMRO).

38 HR 9 juli 2010, ECLI:NL:HR:2010:BM0976 (ASMI), r.o. 4.4.2.

39 HR 4 april 2014, ECLI:NL:HR:2014:797, r.o. 4.2.1, NJ 2014/286 (Cancun). 
'Het bestuur van een doelvennootschap dient zich ook bij de beoordeling van voorstellen van een potentiële bieder ${ }^{40}$, onder toezicht van de raad van commissarissen, te richten op - in de termen van de Corporate Governance Code - de langetermijnwaardecreatie van de vennootschap en de met haar verbonden onderneming en daartoe de in aanmerking komende belangen van de stakeholders te wegen. ${ }^{41}$

Vorenstaande analyse leidt tot de conclusie dat rechters het zelfstandige belang van een vennootschap in vijandige overnames juridisch erkennen en daar zelfs materialiteit aan toekennen in de vorm van langetermijnwaardecreatie, die bovendien juridisch afdwingbaar is gebleken in Akzo Nobel. Tevens blijkt uit Cancun en Akzo Nobel dat het belang van de vennootschap in haar langetermijnwaardecreatie begrensd wordt door de redelijkheid en billijkheid. Het actief bevorderen van het belang van de vennootschap door het bestuur mag niet tot onevenredige schade van de belangen van stakeholders leiden. Conform Cancun houdt dit laatste in dat bestuurders in beginsel enkel een negatieve plicht hebben jegens de stakeholders van de vennootschap. Anders gezegd, van het bestuur wordt niet gevergd een of meer stakeholdersbelangen actief te bevorderen (tenzij dit uit de statuten van de vennootschap blijkt).

Dit lijkt wellicht tegenstrijdig, te weten dat het bestuur zich moet richten naar het belang van de vennootschap, maar dat van hem niet wordt gevergd een of meer stakeholdersbelangen actief te bevorderen. Dit is echter een logisch gevolg van de visies op het vennootschappelijk belang. Ten aanzien van de inhoud van het begrip 'vennootschappelijk belang' zijn drie benaderingen te onderkennen: (1) de opvatting van het aandeelhoudersbelang, (2) de participantenopvatting en (3) de holistische opvatting. ${ }^{42}$ Deze benaderingen zijn een weerspiegeling van de innerlijke dialectiek van de vennootschap en de met haar verbonden onderneming: deze kan enerzijds als één geheel worden beschouwd, anderzijds als een optelsom van de delen. ${ }^{43}$ Deze dialectiek zorgt enerzijds voor moeilijke afwegingen in de concretisering en vormgeving van langetermijnwaardecreatie, anderzijds creëert deze open norm juist ruimte voor het bestuur om autonoom beslissingen te kunnen nemen en de strategie uit te stippelen. Dit blijkt ook uit de interviews.

40 In Cancun ging het immers niet om een overnamesituatie.

41 Hof Amsterdam (OK) 29 mei 2017, ECLI:NL:GHAMS:2017:1965, r.o. 3.34, JOR 2017/261, m.nt. C.D.J. Bulten (Akzo/Nobel).

42 M.M. Mendel \& W.J. Oostwouder, Lange termijn waardecreatie van de beursvennootschap en de daaraan verbonden onderneming, het bestendige succes van de (dochter)onderneming en het begrip 'vennootschappelijk belang': harmonie of disharmonie?, O\&F (25) 2017, afl. 3, p. 4-18.

43 Deze dialectiek is ook aanwezig in principe 1.1 van de Corporate Governance Code 2016: enerzijds moet het bestuur zich richten op het geheel ('de lange termijn waardecreatie van de vennootschap en de met haar verbonden onderneming'), anderzijds op de samenstellende delen ('weegt daartoe de in aanmerking komende belangen van de stakeholders'). 


\section{Resultaten van de diepte-interviews}

Deze paragraaf bevat de bevindingen van acht diepte-interviews waarin 'actoren in het krachtenveld van vijandige overnames' reflecteren op ontwikkelingen. De acht semigestructureerde interviews werden telkens afgenomen door twee interviewers. Hierin werden verschillende thema's aan de orde gesteld in wisselende volgorde. De specifieke invulling kreeg gestalte door de antwoorden van de participant - waarop werd doorgevraagd door interviewers. Soms kwam het interview daardoor als vanzelf in aanraking met andere verbonden thema's. De interviews werden dan ook niet met een standaardvragenlijst, maar met een lijst van thema's afgenomen. De open semigestructureerde interviews boden de participanten de kans om vrij te spreken over een aantal onderwerpen vanuit hun functies, ervaringen en voorkeuren. De belangrijkste aan de orde gestelde thema's waarover participanten over hun opinie of ervaring zijn gevraagd, zijn:

- een aantal grote overnameconflicten;

- internationale ontwikkelingen in kapitaalmarkten;

- corporate governance, recente rechterlijke uitspraken en invoering van langetermijnwaardecreatie als norm in het Nederlandse corporate-governancesysteem;

- rol van het vennootschappelijk belang;

- de relatie langetermijnwaardecreatie en aandeelhouderswaarde.

De participanten nemen een vooraanstaande positie in en hebben de volgende afkomst:

- participant 1: rechterlijke organisatie;

- participant 2: rechterlijke organisatie;

- participant 3: rechterlijke organisatie;

- participant 4: (non-)executive beursgenoteerde onderneming;

- participant 5: (non-)executive beursgenoteerde onderneming;

- participant 6: (non-)executive beursgenoteerde onderneming;

- participant 7: institutionele belegger;

- participant 8: (voormalig) lid Monitoring Commissie Corporate Governance.

De interviews zijn in het voorjaar van 2018 afgenomen en duurden ongeveer anderhalf tot twee uur. Alle interviews zijn opgenomen, getranscribeerd en gecodeerd. Aan alle participanten is anonimiteit beloofd. In de hiernavolgende paragrafen worden zij aangeduid met een nummer en soms met hun 'afkomst'. De volgende paragrafen bevatten de ideeën en meningen van de participanten op basis van voornoemde thema's, gevolgd door een korte paragraaf waarin wij reflecteren op de voornaamste bevindingen.

\subsection{Het samenvallen van de juridische en de maatschappelijke discussie over corporate governance}

'Rechters zijn geen beleidsvormend orgaan' (participant 1). De participanten uit de rechterlijke organisatie geven er de voorkeur aan om zich te onthouden van deelname aan discussies met betrekking tot het belang van de vennootschap, lan- 
getermijnwaarde, duurzaamheid, aandeelhouders- of stakeholderswaarde - vraagstukken die volgens hen de wetgever dient op te lossen. In overnamegeschillen zijn rechters gehouden tot marginale juridische toetsing op basis van open normen. Dit mechanisme zorgt ervoor dat het bestuur gebruik kan maken van zijn discretionaire bevoegdheid om besluiten te nemen in het vennootschapsbelang. Deze participanten benadrukken dan ook dat rechters geen standpunt zullen innemen ten aanzien van het beleid van de vennootschap - dat is het domein van het bestuur - en zij zijn evenmin geneigd om de afwegingen van het bestuur inhoudelijk te toetsen. De houding 'rechters volgen, zij vormen niet' (participant 2) wordt dan ook breed gedeeld onder de participanten van de rechterlijke organisatie:

'Dus als de Tweede Kamer zou zeggen: "Nederland moet zo open zijn als het maar kan en alles mag worden overgenomen." Dat is een politieke beslissing, dan gaan wij dat niet tegenhouden.' (participant 2)

Dit standpunt dient kritisch te worden beschouwd. In paragraaf 4 hebben wij laten zien dat het bestuur van de vennootschap zijn taak dient uit te voeren in het belang van de vennootschap en de met haar verbonden onderneming. Het belang van de vennootschap is een open norm. Die open norm geeft niet alleen het bestuur beoordelingsvrijheid bij het nemen van besluiten, maar ook de rechter bij het toepassen van de norm in een specifiek geval. Participanten van de rechterlijke organisatie stellen dat rechters in Cancun en Akzo Nobel simpelweg de open norm hebben toegepast, zoals zij daartoe verplicht zijn binnen de grenzen van het Nederlandse recht. Aan een van de participanten werd de volgende vraag voorgelegd: 'In Cancun wordt gesproken over het bestendige succes van de onderneming. Hoe ziet u de toepassing van deze norm in relatie tot de maatschappelijke ontwikkelingen?' Hierna volgt een inzichtelijke overweging:

'Het uitgangspunt is natuurlijk wat er in de wet staat. Ook voor ons, wij kijken natuurlijk eerst in de wet, wat de parlementaire geschiedenis daarbij is en wat de gevolgen zijn van een bepaalde uitleg. De rechter past daarbij alle uitlegmethodes toe. Hoe je iets uitlegt, kan wel in de tijd veranderen. We zijn toch veel soepeler geworden in het uitleggen van allerlei gevolgen, mede in het licht van redelijkheid en billijkheid. Ik denk dat de goede trouw van vroeger toch een wat minder prominente rol speelde dan nu de redelijkheid en billijkheid. Bij die uitleg, waar de rechter dus nog keuzeruimte heeft, denk ik dat het maatschappelijke debat een rol speelt. (...) Wij hebben als rechters natuurlijk wel speelruimte, maar het is toch wel allemaal binnen de grenzen van de wet, de toelichting en de gevolgen van een bepaalde uitleg. Waar een norm opening biedt, houd je rekening met het maatschappelijk debat. Als een hoogste rechter zegt dat het vennootschapsbelang in de regel wordt bepaald door het bevorderen van het bestendige succes van de onderneming, ligt daarin niet een eigen opvatting van de rechter besloten. Als een rechter dit overweegt, zal hij denken: "Dit is nu breed gedragen. Het ligt ten grondslag aan Nederlandse regelgeving. Het staat op verschillende plekken. We kunnen 
veilig zeggen: het vennootschapsbelang wordt in de regel vooral bepaald door het bevorderen van het bestendige succes van de onderneming." Ik denk dat in dit soort gevallen rechters eerder volgend zijn.' (participant 2)

De beoordeling van de procedure, niet de beoordeling van de inhoud van het bestuursbesluit, valt onder de rechterlijke toetsing. Rechters onderzoeken welke regels gevolgd zijn, welke deelnemers betrokken waren bij de procedure en wiens belangen in acht zijn genomen. Het vennootschapsbelang wordt door rechters gebruikt als sleutel om de rechtmatigheid van genomen keuzes te toetsen, aangezien het vennootschapsbelang wettelijk is opgenomen. Alleen wanneer het bestuur de grenzen van het vennootschapsbelang overschrijdt, zal de rechter dit belang als norm handhaven. Anders geformuleerd: het vennootschapsbelang geldt als gedragsnorm voor het bestuur en als toetsingsnorm voor de rechter.

\subsection{Aspecten van het vennootschapsbelang}

Onder de participanten bestaat overeenstemming dat het de taak van het bestuur is om het belang van de vennootschap vast te stellen. Een hierop aansluitend probleem is welke aspecten van belang kunnen zijn om vast te stellen wanneer het beleid van de vennootschap dan wel de bestuursbesluiten in lijn zijn met het vennootschapsbelang.

Verschillende aspecten worden genoemd, waaronder: de aard van de vennootschap (bijvoorbeeld of er sprake is van nationale veiligheid of nationaal belang), statutaire bepalingen, het hebben van een helder beeld van de stakeholders van de vennootschap, inclusief hun belangen, en de consequenties van een overname. Pogingen tot een vijandige overname mogen het belang van de vennootschap niet disproportioneel schaden. Zo moet het bestuur van de doelvennootschap een helder beeld vormen van de consequenties van de acquisitie voor de vennootschap en de met haar verbonden onderneming, rekening houdende met de werkgelegenheid, het mededingingsrecht en eventuele synergieën. Vooral in een rustige periode zou elk bestuur duidelijk moeten formuleren wat het belang van de vennootschap omvat en welke belangen en beleidslijnen hier onderdeel van zijn, bijvoorbeeld de milieutechnische en maatschappelijke beleidslijnen. Een duidelijke formulering, ex ante, van het belang van de vennootschap door het bestuur vergroot kennelijk de geloofwaardigheid van zijn handelen tegenover de stakeholders van de vennootschap, waaronder ook de aandeelhouders in een overnamepoging. Zoals een van de participanten het zegt:

'(...) als je dus echt verrast wordt, is er iets aan de hand. Normaliter doet een partij dat niet zomaar. We zitten nu ook in een andere tijd. Ik denk dat je als bestuur of raad van commissarissen veel meer vooruit moet denken in plaats van beschermen en afschermen. Dat is niet meer duurzaam.' (participant 6)

Dit argument wordt overigens ook breder ondersteund dan enkel onder de bestuurders en commissarissen die deelnemen aan dit onderzoek. Meerdere participanten geven aan dat het bestuur, gedurende een vijandige overname, een lijst 
met omstandigheden doorloopt waaraan, in het belang van de vennootschap, moet worden voldaan. Die lijst bestaat onder andere uit een eerlijke prijs, de belangen van de stakeholders van de vennootschap en, indien van toepassing, de nationale veiligheid, en of de potentiële koper kon worden aangemerkt als een bonafide koper.

Hoewel geen van de participanten kan ontkennen dat aandeelhouders een sterke positie hebben in een naamloze vennootschap, is de meerderheid van de participanten het erover eens dat een doordachte strategie die geloofwaardig, verdedigbaar, up-to-date, adequaat gecommuniceerd en transparant is, de CEO speelruimte geeft om een langetermijnstrategie vast te stellen en uit te voeren. De beste bescherming van een vennootschap zijn niet geavanceerde beschermingsmaatregelen, maar een deugdelijk en duidelijk beleid en een strategie gericht op langetermijnwaardecreatie:

'Het Nederlandse vennootschapsrecht is zo'n leuke toverdoos vennootschapsrecht dat je misschien niet eens altijd dat beschermingsrecht nodig hebt omdat er zo veel andere middelen zijn waarmee je je als bestuur ook in verweer kan stellen.' (participant 3)

Bovendien zijn er risico's verbonden aan het activeren van een beschermingsconstructie:

'Weet je hoe erg je moet oppassen om een beschermingsconstructie in te roepen? Als je geen deal maakt met een bieder en de afwijzing is niet meteen duidelijk, dan lopen je goede mensen weg. De factor people is het grootste risico in een biedingsproces - zowel voor de aanvaller als voor de verdediger.' (participant 4)

\subsection{Langetermijnwaardecreatie}

De herziene Corporate Governance Code is ook onder de aandacht van de participanten gebracht. Volgens de Code moet de vennootschap streven naar langetermijnwaardecreatie, op een manier waarmee het belang van de vennootschap en de met haar verbonden onderneming is gediend. ${ }^{44}$ Een overname kan vanuit die gedachte de beste optie zijn voor een vennootschap en de met haar verbonden onderneming, in het bijzonder in de situatie waarbij hoge investeringen nodig zijn om op lange termijn het zelfstandige voortbestaan van de vennootschap te waarborgen, terwijl financiering onzeker is. De belangrijke toetsing daarbij is of (een groep) stakeholders niet disproportioneel in hun belangen worden geschaad.

De algemene opvatting is dat concepten als het succes van een onderneming, de continuïteit van de onderneming en de langetermijnwaardecreatie overlappen. Participanten interpreteren langetermijnwaardecreatie echter verschillend. Bestuurders hebben de neiging om langetermijnwaardecreatie te interpreteren als 
het vinden van de juiste balans in de handelingen van het bestuur voor de verschillende stakeholders van de vennootschap. Investeerders zien langetermijnwaardecreatie in het algemeen als 'meer omvattend dan het belang van de vennootschap'. Soms hinkt men op verschillende gedachtes:

'Ik vind dat ik daar aan de ene kant heel genuanceerd en gebalanceerd in zit. Aan de andere kant zit ik er heel strak in en voor sommigen ook wel eens wat Angelsaksisch. Voor mij is langetermijnwaardecreatie een juiste balans in de dingen die je presteert voor de verschillende stakeholders. Dan heb ik het over klanten, medewerkers, aandeelhouders en society. Ook nog de overheid. Indirect de BV Nederland. Dat zeg ik er dan heel specifiek bij. Dat geldt wat mij betreft niet voor elk bedrijf. Dus een bedrijf als (...) daar geldt dat laatste niet. Wat de overheid er ook van vindt.' (participant 5)

Het maatschappelijk belang speelt een belangrijke rol, zeker bij strategische ondernemingen of cruciale (digitale) infrastructuur, veiligheid en privacy.

Langetermijnwaardecreatie bestaat ook uit prestatiecriteria van een vennootschap met betrekking tot het milieu, de maatschappij, de governance en andere niet-financiële waarden (participant 7). Deze participant stelt ook dat niet-financiële waarden duidelijker naar voren zouden moeten komen in de langetermijnstrategie van een vennootschap.

De huidige opvattingen en discussies over aandeelhouders- versus stakeholdersbelangen en langetermijnwaardecreatie kunnen worden gezien als een reactie op de angst voor de korte termijngerichtheid van de kapitaalmarkt. Het omvallen van Fortis/ABN AMRO, met de grote negatieve gevolgen voor de nationale economie, heeft diepe wonden geslagen. Een aantal participanten spreekt dan ook van 'het ABN AMRO-trauma'. De les die zij uit het ABN AMRO-trauma trekken, is dat in een biedingsproces van aandeelhouders niet kan worden verwacht dat zij hun handelen laten afhangen van andere factoren dan de hoogte van de prijs. Zie de twee voorbeelden hierna:

'Ik denk dat je veilig kunt zeggen dat we in Nederland van een stakeholderbenadering uitgaan. Dat heeft invloed op de norm voor het vennootschappelijk belang. Dat zag je bijvoorbeeld in de ABN Amro-zaak waar Barclays niet het beste was voor de aandeelhouders maar wel voor alle stakeholders, volgens het bestuur van ABN Amro dan. Dan kan het bestuur zeggen: "Wij vinden het in het vennootschappelijk belang om met die partij verder te gaan. Weliswaar biedt zij niet de allerhoogste prijs, maar haar bod is wel het beste voor de onderneming". Die afweging kan het bestuur binnen de reikwijdte van het vennootschappelijk belang maken. Ik geloof niet dat een rechter zal zeggen: "Nee dat is niet in het vennootschappelijk belang". Daarmee zou de rechter op de stoel van de ondernemer gaan zitten.' (participant 2)

'(...) dat vennootschappelijk belang is eigenlijk opgebouwd uit een heel brede groep stakeholders. Het is niet meer dan logisch dat het bestuur tot een con- 
clusie kan komen die niet parallel loopt met de belangen van de aandeelhouders. Zeker in zo'n overnamesituatie, want daar heb je natuurlijk aandeelhouders die... als ze graag willen dat die overname doorgaat... eigenlijk zal het ze plat gezegd worst wezen wat er verder met die onderneming gebeurt. Als de koers 50 is en het bod is 80 en je denkt, ik wil heel graag uitstappen voor 80 , dan mag van jou verder een maand later die onderneming omvallen als jij die 80 maar hebt. Dat is ook prima, daar kun je ethisch of moreel ook niets van zeggen, dat klopt helemaal. De consequentie is wel dat de uitkomst van een afweging die meer en andere belangen omvat, tot een ander resultaat kan leiden dan wat de aandeelhouder wenst. Dat vind ik echt niet meer dan elementaire logica. Ik vind daar niet een stap in zitten.' (participant 1)

Er lijkt dus ook volgens de resultaten uit de interviews een consensus te bestaan dat het zelfstandig belang van de vennootschap van het deelbelang van de aandeelhouder kan worden onderscheiden en dat hieraan in bepaalde gevallen voorrang kan worden gegeven. Een aantal participanten meent dan ook dat vanwege de druk van de kapitaalmarkt bestuurders wel degelijk beperkt worden om een gedegen ondernemingsbeleid te ontwikkelen en te implementeren. Een van de participanten uit de rechterlijke organisatie omschrijft dit als een 'sad state of affairs' (participant 3). Rechters kunnen echter niet alle (juridische en niet-juridische) overwegingen openbaar maken in hun uitspraken. Uit de gesprekken blijkt allerminst dat de magistratuur zich de maatschappelijke ontwikkelingen niet aantrekt.

Participant 3: 'Ik denk dus dat Amerikaanse bieders in Nederland niet gunstig ontvangen worden over het algemeen. Die hebben toch een reputatie... Als het gaat om America First... ja, moeten wij dat dan allemaal gaan zitten bevorderen hier? Dat lijkt me niet. Dat heeft in die strijd van Akzo wel een rol gespeeld. Ik denk dat men heeft gedacht: "Ja, hoor eens, hoe betrouwbaar is PPG nu eigenlijk.” (...) en China komt natuurlijk ook steeds meer op.'

Interviewer 1: 'Zijn die Chinese investeerders niet juist op de lange termijn gericht?'

Participant 3: 'De lange termijn voor China, maar voor Nederland? Ik weet niet of zij de Nederlandse belangen voldoende zwaar laten meewegen (...).'

Interviewer 1: 'Wat zijn dan de Nederlandse belangen?'

Participant 3: 'Om je werkgelegenheid in stand te houden, R\&D en economische activiteit. Als een hele onderneming overgeheveld wordt naar China, daar hebben wij niet zo veel belang bij, lijkt mij. Alle research die daarvoor heeft plaatsgevonden... China is natuurlijk een geweldig sterk land geworden met een enorm grote groep technisch hoogopgeleide mensen die heel veel kunnen met de technologie die hier ontwikkeld is. Moeten wij dat allemaal bevorderen?'

Interviewer 1: 'Dat is wel heel politiek?'

Participant 3: 'Dat is niet het verhaal wat je in de uitspraken tegenkomt. Je hebt allerlei instrumenten om zo'n overname te vertragen. Ik denk dat het recht beperkt is, maar wel belangrijk. Je kunt op basis van het Nederlandse 
vennootschapsrecht met de hulp van de rechter een overnameproces vertragen en ervoor zorgen dat we weten wat we aan het doen zijn met zijn allen. Ik geloof helemaal niet dat je als rechter de wil en de pretentie moet hebben om over al die plannen echt een oordeel te hebben, maar wel dat je doorziet: hier gebeurt wat belangrijks en we moeten ervoor zorgen dat alles op tafel komt wat relevant is. Ik vind dat de rechter uiteindelijk niet moet beslissen, maar het kan een hulpmiddel zijn dat je zegt: Het bestuur heeft plannen, strategie, wij oordelen wat terughoudend daarover, dat is marginale toetsing en in beginsel krijgt het bestuur van ons gelijk. Als aangetoond kan worden dat die plannen helemaal niet deugen, dan wordt het wel een ander verhaal. Dan kun je tegen het bestuur zeggen: Dat komt toch allemaal niet zo fortuinlijk over. Voorlopig moet er maar niets gebeuren. Komen jullie maar eens met een beter verhaal.'

Elders formuleert participant 3 het als volgt:

'Als je een goede strategie hebt en je kunt vertellen van wij willen dat en dat en daar zijn we mee bezig om dat uit te voeren. En dat is redelijk goed verdedigbaar. Ja dan zie ik niet rechters zo makkelijk zeggen van geef maar ruim baan aan de bieder of de overnemer.'

De rechterlijke houding lijkt te zijn 'wij gaan niet meewerken aan een vijandige overname, tenzij ...' Dat laatste wordt marginaal getoetst. Rechters lijken wel beducht voor de consequenties van hun uitspraak, aangezien dit de deur kan openen voor een onbeheersbaar en risicovol proces, dat - gezien de marktdynamiek mogelijk onomkeerbaar is, zoals blijkt uit het ABN AMRO-trauma. Het lijkt erop dat rechters geneigd zijn om het proces af te remmen, zodat een evenwichtige beoordeling door het bestuur onder toezicht van de raad van commissarissen kan plaatsvinden ten aanzien van de trade-offs van een eventuele overname. Een vijandige overname wordt bovendien beïnvloed door veel lobbywerk van advocaten, banken, activistische aandeelhouders en de vennootschap zelf. Ook de maatschappelijke onrust speelt een rol, zoals participant 5 (non-executive beursgenoteerde onderneming) aangeeft:

' $[\mathrm{H}]$ et politieke sentiment is dat je hier [het beschermen van de bieder; JN e.a.] beter mee scoort als politicus, minister, staatssecretaris, dan als je het gewoon rationeel en zakelijk bekijkt. Het is ook gewoon not-done om te zeggen de beste verdediging is een goeie performance. Bijna niemand durft dat te zeggen.'

Het creëren van rust (of het vertragen van het proces) om - voor zover mogelijk feiten van fictie te onderscheiden is dan essentieel. Rechters zien dat als een belangrijke taak.

Participant 7 (institutionele belegger) benadrukt de status van langetermijnwaardecreatie als een juridisch afdwingbare norm, met name in de situatie van een vij- 
andige overname. Participant 7 illustreert het belang van langetermijnwaardecreatie in een vijandige overname als volgt:

'Een vijandige overname heeft eigenlijk twee kenmerken. In de eerste plaats impliceert een vijandige overname dat er geen dialoog plaatsvindt tussen de betrokken partijen. Niet echt... ja, er kan misschien met het mes op tafel een gesprek van een half uur plaatsvinden met advocaten erbij... maar van een echte dialoog is geen sprake. Ten tweede wordt er niet gedaan aan due diligence. Wanneer het gaat om langetermijnwaardecreatie, dan zul je verder moeten kijken dan alleen de gepubliceerde jaarverslagen. Het is belangrijk om te kijken naar bijvoorbeeld de invloed van innovaties. Zulke dingen zijn afhankelijk van factoren die niet gerapporteerd zijn in jaarverslagen. Een gedegen onderzoek is hiervoor essentieel. Wanneer er geen sprake is van goed onderzoek vooraf, betaalt de overnemende partij bijna altijd teveel. Wat ik graag zou zien, is dat beleggers zouden zeggen: Wij werken niet mee aan vijandige overnames, want dat is strijdig met langetermijnwaardecreatie. Wij werken alleen mee met overnames waarbij er op zijn minst sprake is van een serieuze poging tot dialoog door de overnemende partij. Daarbij moet er due diligence hebben plaatsgevonden.'

Het zittende bestuur zal zich over het algemeen verzetten tegen het bieden van toegang tot 'due diligence' op het moment dat hij geconfronteerd wordt met een ongevraagd bod. Zodoende roept participant 7 bestuurders en aandeelhouders op om kritisch te reflecteren op de vraag of een vijandige overname überhaupt een geschikt instrument dan wel strategie is om waarde te creëren voor de vennootschap. Zonder dialoog en 'due diligence' kan een biedende vennootschap blootgesteld worden aan buitensporige risico's, wat mogelijk ook niet in het langetermijnbelang is van de doelvennootschap.

\subsection{Steun voor en kritiek op langetermijnwaardecreatie}

Participanten lijken het belang van langetermijnwaardecreatie als norm te ondersteunen; ook institutionele beleggers betuigen in beginsel hun steun. Zoals participant 7 opmerkt, lijken aandeelhouders meer waarde te hechten aan langetermijnwaardecreatie dan ooit tevoren. Neem bijvoorbeeld de eerder besproken nietfinanciële waarden die aan belang toenemen in de besluitvorming van investeerders en aandeelhouders. De betreffende participant benadrukt echter wel dat bestuurders in de wijze waarop zij verantwoording afleggen over de niet-financiële prestaties van de betreffende ondernemingen een verbeteringsslag kunnen maken. Daarnaast is het kennen van je langetermijnaandeelhouders van groot belang, zeker als er een stabiele groep institutionele beleggers zit die het bestuur steunt:

'Je moet je oren niet laten hangen naar zo'n activist. Het kan zijn dat zo'n bestuur te snel in paniek raakt. Dat moet je niet hebben. Je moet eigenlijk continu als bestuur weten wat er speelt onder die trouwe schare van lange termijn institutionele beleggers. (...) In Nederland staat nog niet voldoende 
op het netvlies dat het een taak is van het bestuur en met name ook de raad van commissarissen om die band met lange termijn aandeelhouders goed te houden, hen te kennen en ook te weten hoe zij tegenover de strategie staan. Als er dan een activist komt, dan hoef je niet meteen in paniek te raken en te zeggen, nou, hup, die divisie gaan we verkopen.' (participant 7)

Er is ook kritiek op langetermijnwaardecreatie als norm. Het risico bestaat dat een dergelijke open norm als panacee functioneert voor slechte resultaten. Langetermijnwaardecreatie is nauwelijks definieerbaar; dit kan opportunistisch gedrag uitlokken:

'Uiteindelijk kunnen die normen worden misbruikt. Een goede ondernemer is natuurlijk ook redelijk opportunistisch ingesteld. Die bedenkt hoe kan ik dit gebruiken. Dan wordt dus de interessante vraag, hoe legt hij het vast. Ik zou het zelf wel interessant vinden als nu een monitorcommissie zou gaan kijken, hoe nu eigenlijk ondernemingen het begrip langetermijnwaardecreatie invullen.' (participant 8)

Participant 7 (institutionele belegger) stelt dat in het geval van een openbaar bod niet het bestuur, maar de aandeelhouder in beginsel in de 'driver's seat' zit. Volgens deze participant zou langetermijnwaardecreatie geen rol mogen spelen bij een openbaar bod. De participant bepleit dat in het geval van een overnamebod er geen going concern-conceptie van de doelvennootschap bestaat of mag zijn. De aandeelhouders zullen hun beslissing over het al dan niet verkopen van hun aandelen baseren op de geboden prijs. Daarom zou de geboden prijs richtsnoer moeten zijn voor het bestuur van de doelvennootschap. Aan de andere kant benadrukt participant 7 dat het bestuur van een Nederlandse beursvennootschap een bod mag afwijzen en frustrerende maatregelen mag treffen:

'Als een vijandige bieder dan wel doorzet, dan moet de aandeelhouder afwegen of op lange termijn meer waarde kan worden gecreëerd onder de huidige, zelfstandige strategie met het zittende management dan wel dat de onderneming op lange termijn beter gebaat is bij een sterke moeder. De aandeelhouder zal moeten beoordelen of de geboden prijs een goede weerspiegeling is van de waarde die de onderneming op lange termijn zou hebben gecreëerd in een stand-alone situatie. Als de prijs lager is, dan zal hij in principe minder genegen zijn om op het bod in te gaan. Hij zal in zijn beoordeling echter ook de opvattingen van andere partijen moeten verdisconteren, omdat een aandeelhouder het risico loopt met een moeilijk verhandelbaar, niet liquide aandeel te blijven zitten waarbij de macht na gestanddoening van het bod is geconcentreerd bij de bieder.'

Het bod (en de uiteindelijke overnameprijs) is dan ook een belangrijke factor in een overnamesituatie. In de ideale situatie worden financiële en niet-financiële waarden in de prijs meegenomen: 
'Alles komt terug in de prijs. Wat ik net zei, je hebt een waarderingsmodel, daar zit alles in. Daar zit duurzaamheidsbeleid, cultuur, et cetera, allemaal in. Uiteindelijk gaat het natuurlijk wel om hoe die waardecreatie wordt berekend.' (participant 7)

Vorenstaande opvatting staat op gespannen voet met de zienswijze van de geïnterviewde rechters. Het (zelfstandige) belang van de vennootschap kan volgens hen afwijken van het belang van de aandeelhouders om een zo hoog mogelijke prijs te ontvangen. In het Nederlandse recht mag het bestuur van de doelvennootschap rechtsgeldig tegen de belangen van de aandeelhouders in besluiten. Zoals participant 1 benadrukt, zijn de vennootschap en het bestuur gehouden om de langetermijnwaarde van de vennootschap en de met haar verbonden onderneming te bevorderen. Het lijkt erop dat er brede steun is onder rechters en de Monitoring Commissie dat langetermijnwaardecreatie een juridisch afdwingbare norm in overnamesituaties is geworden: 'Dat is wat de rechter heeft geoordeeld' (participant 1).

\subsection{Reflectie op de resultaten van de diepte-interviews}

De communis opinio is dat open normen (vennootschappelijk belang en redelijkheid en billijkheid) geleidelijk zijn geïntroduceerd in de context van overnames. Het belang van de vennootschap en de met haar verbonden onderneming, langetermijnwaardecreatie, bestendig succes, duurzaamheid en continuïteit zijn inmiddels geconsolideerd als rechtsnormen in Nederland. Kortetermijnaandeelhouderswaarde, een harde, eendimensionale economische norm, lijkt aan waarde in te boeten ten gunste van een zachte, multidimensionale rechtsnorm, langetermijnwaardecreatie. Sommige participanten stellen dat de verschuiving in de Nederlandse corporate governance van aandeelhouderswaarde naar langetermijnwaardecreatie een reactie is op vijandige overnames die omvangrijke negatieve gevolgen hadden voor de Nederlandse economie (het ABN AMRO-trauma), dan wel is ontstaan door een toegenomen intolerantie voor (toekomstige) overnamepogingen waarvan de risico's niet zijn te voorzien. Anderen koppelen deze verschuiving tevens aan de vermeende kortetermijndruk van de kapitaalmarkten. Dit neemt niet weg dat bestuurders, commissarissen en institutionele beleggers nog steeds een belangrijke rol voor de kapitaalmarkten zien, ongeacht welke open rechtsnormen van toepassing zijn. Institutionele beleggers voelen - wellicht meer dan bestuurders en commissarissen - de druk van de kapitaalmarkt. Zij dienen primair te handelen in het belang van hun achterban. Zoals participant 7 bevestigt: ' $[\mathrm{H}]$ et is moeilijk aan je achterban uit te leggen wanneer je niet zou kiezen voor het hoogste bod.'

Op bestuurders rust de wettelijke taak om het vennootschappelijk belang te beschermen en te bevorderen. Deze open norm is echter slechts beperkt afdwingbaar. Bestuurders zijn relatief autonoom in de keuze voor een strategie. De bestuurder is in principe de best uitgeruste persoon om zo'n beslissing te nemen. Echter, niet elke strategie is plausibel, houdbaar of haalbaar in het kader van langetermijnwaardecreatie. Een up-to-date strategie die verschillende compromissen 
bevat, zou een vennootschap kunnen beschermen tegen een vijandige overname en biedt bestuurders ruimte voor maatregelen. Deze bescherming is niet ongelimiteerd, aangezien de strategie en de reactie op het bod overtuigend moeten zijn.

Rechters zijn beducht voor onbekende consequenties van een vijandige overname; er zijn hoge risico's bij betrokken wanneer een vennootschap haar markt of productportfolio aanpast. Zelfs in het geval waarbij de keuze voor een stand-alone strategie niet altijd de beste optie is, zijn rechters, met de kennis van 'het nu', terughoudend in het actief in beweging brengen van een mogelijk onomkeerbaar proces waarbij zorgvuldige afweging van het overnamebod niet langer mogelijk is.

Er zijn in dit overnamespectrum twee uitersten te onderkennen: aandeelhouderswaarde enerzijds versus langetermijnwaardecreatie anderzijds. Bij aandeelhouderswaarde gaat het om de uitkomsten van een strategie in termen van de beurskoers, bij langetermijnwaardecreatie om het daaraan ten grondslag liggende besluitvormingsproces dat meerdimensionaal is. Er lijkt dan ook meer nadruk te komen liggen op de menselijke maat - het primaat van de aandeelhouderswaarde is verdwenen. De laatste jaren is echter sprake van een toenemende wet- en regeldruk die juist een 'crowding out'-effect kan bewerkstelligen van het moreel kompas van bestuurders. Ook door de extra wet- en regelgeving kan de menselijke factor worden uitgehold: de druk van de kapitaalmarkt wordt vervangen door de druk van de wet- en regelgeving. De toenemende wet- en regelgeving kan immers leiden tot een veronachtzaming van zachte waarden als cultuur, vertrouwen en legitimiteit. Winter spreekt in dit verband over de 'ontmenselijking van de grote onderneming'. ${ }^{45}$ Uit de interviews blijkt echter niet dat participanten een toename in de regeldruk ervaren en geen belang hechten aan de menselijke factor. Termen als vertrouwen, cultuur, commitment, afwegingen, overtuigen, geloofwaardigheid en discussie worden veelvuldig gebruikt en spreken dit 'bestuurlijk verval van het moreel kompas' tegen. Dit past bij de door ons besproken trend in de jurisprudentie ten aanzien van het zelfstandig belang van de vennootschap. Hierin wordt steeds meer waarde toegekend aan de waardering van het handelen van het bestuur. Dat kan worden onderscheiden van andere deelbelangen, zoals het aandeelhoudersbelang.

\section{Slot}

Zowel in de jurisprudentie als uit de interviews lijkt meer ruimte en aandacht te zijn voor langetermijnwaardecreatie. De norm van langetermijnwaardecreatie overstijgt de dichotomie tussen het shareholder- en stakeholdermodel en roept de vraag op naar een verdere theoretische fundering hiervan, mede in de zelfstandige betekenis van het belang van de vennootschap en de daarmee verbonden 
onderneming. ${ }^{46}$ Er kan wellicht worden gesproken van een verschuivend paradigma in corporate governance bij vijandige overnames, waarbij niet zozeer de achterliggende partijen (share- of stakeholders) van de vennootschap centraal staan, maar de vennootschap en de bronnen van de met haar verbonden onderneming. Dit zorgt voor een tegenstrijdig krachtenveld dat samenhangt met de verschillende concepties van de vennootschap en de met haar verbonden onderneming. Uit de interviews blijkt duidelijk dat langetermijnwaardecreatie in de afwegingen bij een vijandige overname een centrale positie krijgt of dient te krijgen. De innerlijke dialectiek zorgt enerzijds voor moeilijke afwegingen, maar anderzijds ook voor ruimte om autonoom (maar in samenspraak met alle stakeholders) een bepaalde strategie uit te stippelen. De ontwikkeling van de wet- en regelgeving komt dan ook in grote lijnen overeen met de reflecties van de participanten.

De meerderheid van de participanten beschouwt aandeelhouderswaarde of de hoogte van het bod in een overnamesituatie als een te eenvoudige, onnauwkeurige maatstaf van de waarde van de vennootschap - het nastreven van aandeelhouderswaarde kan het belang van de vennootschap en van de samenleving als geheel ernstig schaden. ${ }^{47}$ De invloed van het ABN AMRO-trauma op de participanten is aanzienlijk. Participanten uit de rechterlijke organisatie en de Monitoring Commissie benadrukken de risico's en eventuele maatschappelijke gevolgen van een vijandige overname, terwijl bestuurders en commissarissen zich veelal willen openstellen voor nieuwe 'opportunities'.

De verschuiving van aandeelhouderswaarde naar langetermijnwaardecreatie is ook academisch gezien van grote betekenis. Door de introductie van langetermijnwaardecreatie heeft het belang van de vennootschap een meer pregnante zelfstandige (bedrijfswetenschappelijke) betekenis gekregen. Die zelfstandige betekenis van het vennootschappelijk belang heeft tot gevolg dat de vennootschap in beginsel bovengeschikt is aan haar stakeholders, waaronder ook haar aandeelhouders. De Nederlandse corporate governance biedt dan ook een interessant alternatief perspectief voor een nieuw model dat de dichotomie van het shareholder- en stakeholdermodel overstijgt, weergegeven door concepten als langetermijnwaardecreatie en vennootschappelijk belang. Deze concepten vragen om een theoretische grondslag ${ }^{48}$ waarin de onderneming wordt beschouwd als

Deze discussie is niet nieuw; al in 1930 debatteerden Berle en Dodd over de ontologische existentie van de vennootschap als een afzonderlijke entiteit, zie J. Robé, The legal structure of the firm, Accounting, Economics, and Law (1) 2011, afl. 1, p. 1-86.

47 KPMG heeft hiervoor in 2014 het begrip 'true value' geïntroduceerd: KPMG, Introducing KMPG true value, a tool to connect corporate and societal value creation, 2014, https:// home.kpmg.com/content/dam/kpmg/ae/pdf/introduction-kpmg-truevalue.pdf.

48 Zie bijv, V. Bavoso, The corporate law dilemma and the enlightened sovereign control paradigm. In search of a new legal framework, The Brooklyn Journal of Corporate, Financial and Commercial Law (12) 2018,afl.2, p. 1, A. Keay, Ascertaining the corporate objective. An entity maximisation and sustainability model, Modern Law Review (71) 2008, afl. 5, p. 663-698 en D. Attenborough, Giving purpose to the corporate purpose debate. An equitable maximisation and viability principle, Legal Studies (32) 2012, afl. 1, p. 4-34. 
een synthese tussen de verschillende bedrijfsmiddelen (en niet in termen van de achterliggende stakeholders waartussen conflicten bestaan). Door de nadruk op het samenstel van bronnen en niet zozeer op de aanspraken op die bedrijfsmiddelen verschuift de aandacht naar bedrijfswetenschappelijke inzichten.

Het belang van inzichten uit de financieringstheorie en het klassieke op financiële prestaties gerichte jaarverslag voor corporate governance neemt af, ten faveure van inzichten van strategisch management, ${ }^{49}$ risico's en business models. Niet (alleen) het onbekende eindresultaat, maar ook het proces van waardecreatie wordt van belang, waarbij een ruimere doelstelling en een bredere vorm van rapportering passen. ${ }^{50}$ De vennootschap en de met haar verbonden onderneming zijn deels ongrijpbaar - dat is zelfs nodig voor hun voortbestaan. Volledige transparantie is namelijk niet alleen onmogelijk, het is ook ongewenst: het ondergraaft het bestaan van de vennootschap en de met haar verbonden onderneming. Ondernemen is een zoektocht in het onbekende: de 'end of history' ${ }^{51}$ is in vennootschapsland dan ook zeker nog niet bereikt.

49 M.E. Porter \& M.R. Kramer, Creating shared value, Harvard Business Review (89) 2011, afl. 1, p. 2-17.

50 Bijv. via integrated reporting of het verstrekken van niet-financiële informatie, zie A. Brouwer, J. Janssen \& J. Scheffe, De nieuwe Corporate Governance Code en vereisten voor niet-financiële informatie, Maandblad voor Accountancy en Bedrijfseconomie (92) 2018, afl. 11/12, p. 345-359.

51 H. Hansmann \& R. Kraakman, The end of history for corporate law, Georgetown Law Journal (89) 2001, afl. 2, p. 439-468. 